Tér és Társadalom 15. évf. 2001/3-4. 11-24. p.

Tér és Társadalom

XV. évf. 2001 3-4: 11-24

\title{
SZELETEK A TERVEZÉS MÉLYRÉTEGEIBŐL
}

(Slices from the Depth of Planning)

\section{FARAGÓ LÁSZLÓ}

Kulcsszavak:

racionalitás tervezés tervezéselmélet kommunikáció

Jelen tanulmány a tervezéselmélet princípiumainak és dilemmáinak mélyrétegeiböl ragad ki néhány szeletet, melyekkel a szerzô a tervezéselmélet hazai megalapozásához szeretne hozzajárulni. Az alapkérdések tisztázását néhány episztemológiai és etikai megjegyzés vezeti be, majd a tervezés lényegét (, szubsztanciáját") és maximáit vázolja fel a szerzó.

Az egy pártra épülö politikai struktúra mentén centralizált, imperatív tervezés elvetését követően - némi hezitálás után - a gyakorlat kikényszerítette a tervezés újraindítását a közszférában is, de az egyes tervezési iskolák, stílusok és módok megválasztása inkább esetleges, mint tudatos. Ennek egyik oka, hogy alig jelent meg tervezéselmélettel foglalkozó magyar nyelvả munka. A rendszerváltás elött és után is több könyv, tanulmány látott napvilágot, amely a piaci szférában folyó tervezést segíti (pl. Barakonyi-Lorange 1991), de a közösségi (politikai?) tervezés lehetőségeinek és követelményeinek jelentös részét ma ugyanolyan homály fedi, mint korábban.

Kezdjük az alapoknál! Tanulmányunkban a tervezéselmélet princípiumainak és dilemmáinak mélyrétegeiből ragadunk ki néhány szeletet, melyekkel a tervezéselmélet hazai megalapozásához szeretnénk hozzájárulni. Az alapkérdések tisztázását néhány episztemológiai és etikai megjegyzéssel kezdjük, majd a tervezés lényegét (,,szubsztanciajaát”) és maximáit kíséreljük meg felvázolni. Ezek tárgyalására azért van szükség, mert ismeretük hozzájárulhat a tervezési gyakorlat szürke zónáinak felszámolásához, a tudatos és hatékony gyakorlati alkalmazáshoz.

E dolgozatban - reményeink szerint megbocsáthatóan - vulgarizáljuk ${ }^{1}$ a filozófia egyes tanításait, hogy ezáltal megfelelö közelségbe hozzuk, és felhasználhatóvá tegyük ezeket az ismereteket a - filozófiában kevésbé jártas - tervezéselmélet iránt érdeklödő szakemberek számára.

\section{A megkerülhetetlen normativitás és a korlátozott racionalitás}

A társadalmi tervezés jelen gyakorlatában aránytalanul nagy figyelmet (időt és pénzt) fordítanak a helyzetfeltárásra, az úgymond „objektív megalapozásra”, és alig foglalkoznak a célok, prioritások meghatározásának mechanizmusával, az ezek mögött meghúzódó értékvâlasztások megítélésével. Véleményünk szerint a tervezés legfontosabb mozzanata a koncepcionálás (szintézis és döntéshozatal), amely szuikségszerúen normatív tevékenység és ennek tudatosítása, illetve e folyamatok minél jobb megértése és feltárása előbbre vinné a tervezés fejlődését. 
Hume szerint a közvetlen empirikus tapasztalatokból (benyomások, érzetek) keletkeznek az ideák (észleletek), amelyekböl olyan összetett kombinációkat tudunk elöállítani, amelyek nem szükségszerüen tükrözik a benyomások bármely kombinációját. Az ideák között relációkat vagyunk képesek felfedezni, amelyek alapján el tudjuk dönteni, hogy mi elképzelhető és mi nem (Kant 1991; Bánki 1993). Valószínủségi alapon következtethetünk tényekre és ok-okozati összefüggésekre. Éppen ö, aki szándéka szerint az empirikus tudomány megalapozásán dolgozott, erkölcsfilozófiája kifejtése során arra a megállapításra jutott, hogy a tényekböl sohasem vezethetök le értékek. A pozitív és a negatív megítélés csak a megítélö személy helyeslését vagy helytelenítését fejezi ki, bár kétségtelen, hogy az a múltbeli tapasztalatokon nyugszik.

A Hume által felvetett kérdések és válaszok termékenyítőn hatottak Immanuel Kantra. Kant az empirizmus kihívására „kopernikuszi fordulatot” hozott a racionalizmus újragondolásában. „A tiszta ész kritikája” c. mủvében kifejti, hogy a külvilággal kapcsolatos ismereteinket tapasztalati úton nyerjük, de a környezö világot az emberi megismerö-képességnek, szemlélóképességünknek megfelelöen tudjuk csak megismerni. A külső valóságot, a tárgyakat „a priori” ismereteink „,szerkezetében” közelíthetjük csak meg. A gyakorlati ész az akaratot és az elvégzendő cselekvés tartalmát vonatkoztatja egymásra úgy, hogy a cselekvés tartalmát az akarat céljává teszi (Kant 1991 [1788]). Amikor a gyakorlati ész feloldódik pragmatikai használatában, akkor az értelmi tevékenység célracionális igénybevételére redukálódik.

Marxista megközelítésben sem következik a társadalmi és fizikai (természeti és múvi) környezetból az individuális vagy társadalmi cselekvés szükségszerüsége (Márkus 1971). Az individuumok fejlödése, a konkrét döntések az ember és a világ, a tárgyi és társadalmi valóság párbeszédének, egymásra hatásának az eredménye. A (szubjektív) társadalmi lények, az emberek maguk alkotják meg, alakítják életterüket a környezö (objektív) világból. A környezet nem külsődlegesen adott faktum, hanem tudatosan is alakított valóság, amely visszahat az őt alakító egyénekre. Marx által is a legfontosabb emberi jellemzőnek tartott tudatosság lehetővé teszi, hogy saját cselekedeteit, döntéseit vizsgálja és elszakadjon a jelen valóságtól, és mást, újat akarjon. Az emberi tevékenység cél (ideálkép) által vezérelt és a cél által ellenörzött tevékenység ${ }^{2}$. Marxnál ,... a tudat úgy jelenik meg, mint a tevékenységben realizációra váró célok, ideálok, eszmék és értékek 'szellemi termelése',...mint a szubjektív szándékok objektivációjára való törekvés ... „(Márkus 1971, 46), amely nem más, mint a fennálló gyakorlati kontextusban tudatosított (társadalmi) lét. A tudatos gondolkodás Marxnál is ideatorikus. Az embernek „Ahhoz, hogy beilleszkedjen a társadalmi életbe, e 'tanulás', elsajátítás eredményeként ki kell alakítani tudatában a valóság egy olyan viszonylag állandó fenomenális artikulációját, melynek struktúrája megfelel annak az artikulációnak és struktúrának, amely a nyelvben mint a társadalmi tudat objektivációjában tőle teljesen függetlenül adva van." (Márkus 1971, 50)

A tervezés a józan, racionális gondolkodás explicit eszközként megjelenö formája. A tervezés során is általában „a priori” gondolati struktúrával közeledủnk a való- 
ság megismeréséhez és a cselekvési terv kialakításához. Ez az, ami meghatározza a folyamat outputjait, azaz a tervezés típusának, formájának megválasztása alapvető hatással van annak tartalmára is. Az, hogy milyen szándékkal, szemlélettel és eszközökkel vizsgáljuk a kiinduló állapotot meghatározza, hogy mit látunk belőle. Még ha jól is írjuk le a valós világot, akkor is a tények (érzetek) képzetekké, ítéletekké alakítása során nem mindegy, hogy a forma, a struktúra milyen mozgásteret enged az eltérỏ értelmezéseknek, az ész céltételezỏ tevékenységének. Kant terminológiáját használva a tervezés, mint „hipotetikus imperativusz” már előfeltételez egy létezö akaratot és a továbbiakban olyan akarati aktusokat követel, amelyek az első kielégítését szolgálják.

A racionalizmus hívei úgy gondolják, hogy az ész képes a korábbi ismeretek alapján új tartalmi ismeretet létrehozni, míg az empiristák a mentális folyamatokat a környezetböl nyert információk visszatükrözödésének tartják, azaz a tapasztalatot minden ismeret elöfeltételének tekintik.

A racionalizmus megengedi „a priori” tudományos feltételezések és „észigazságok" létét. Sőt, tovább megyünk, a racionalizmus az idealizmus egy változata, hiszen a valóságot a történelmileg alakuló, adott kontextusban létezỏ (társadalmi) tudaton keresztül szemléli. A tervezöi racionalizmusnak éppen az a legfőbb erénye, hogy a jelenségeket tudományosan leképezett „, a priori” struktúrákba helyezi, és azt vizsgálja, hogy milyen törvényszerüségeknek felel, vagy nem felel meg az adott jelenség. A helyzetelemzés - és kevésbé megalapozottan a programalkotás - során a tervező tudományos kategóriákban és a tudomány által megfogalmazott axiómákban, törvényszerüségekben gondolkodik.

A szavakat, a nyelvet az eltérö használatokban meglévö sémákba gyömöszöljük, egyszerüsített modellként (különbözően) értelmezzük. Ugyanez történik a tervezéskor, a koncepcionálás (paradigmálás) fázisában. Az aktor (pl. döntéshozó) saját gondolati struktúrájának megfelelöen értelmezi a tényekről megfogalmazott információkat.

Ad abszurdum feltételezhetỏ egy empirikus vizsgálat és valamely ismérv(ek) mennyiségi növelésére épített stratégia, de a racionalizmus feltételezése nélkül valóban új stratégiákat, jövőképeket nem tudnánk megfogalmazni, és csak a korábbi tapasztalatokon nyugvó kis lépéseket tudnánk megtenni. Albert Einstein írta valahol: „Az intuícióban és az inspirációban hiszek ... van úgy, hogy bizonyosan érzem, hogy igazam van, de nem tudom az okát. ... A képzelőerő sokkal fontosabb, mint a tudás. A tudás korlátozott, míg a képzelőerö átfogja az egész világot, elősegíti a haladást, életet ad a fejlődésnek." A tervezés koncepcionáló fázisában, a célok, a jövőkép megfogalmazása során gyakran el kell szakadnunk az empíriáktól, a jelen kényszerítő nyomorúságától, és merni kell akarni, merni kell változtatni.

Ugyancsak racionális alapon magának a racionalitásnak is határt kell szabni. Racionális önkorlátozás szabja meg, hogy a jelenségek vizsgálatában milyen messze, milyen mélyre kell menni, hogy a tudományos, így a tervezéselméleti eredményeket is megóvjuk a szkepszistöl. Ennek hiányában soha nem gondolkodnánk elöre, nem terveznénk és nem az így kialakított szándékoknak megfelelően cselekednénk, ha- 
nem az újabb és újabb kételyek megoldhatatlanságán filozofálnánk. Ugyanakkor a racionalizmus talaján nem vállalkozhatunk a végső igazság vagy akár a társadalmi igazság meghatározására, legföljebb olyan struktúrákat alakíthatunk ki, olyan folyamatokat játszhatunk le, amelyek az ott és akkor érvényes igazság minél jobb feltárását szolgálják.

Gyakori tévhit, hogy a tervezői tevékenység, a végrehajtás és az ellenőrzés elkülöníthető a társadalmi egyeztetéstöl és a szubjektív értékválasztásokon alapuló döntéshozataltól, és ezáltal a tervezés nemcsak racionálisnak, hanem objektívnek is tekinthetö. Ez számos feltétel teljesülése esetén, meghatározott tervezési eljárások esetében elméletben akár igazolható is, mert léteznek a tervezésnek olyan formái, ahol a tények birtokában objektív választásra nyílik lehetőség. De annak ellenére, hogy a tervezési folyamat jelentös része a tudományos racionalizmus alapján kezelhető, akár pozitivista alapokra helyezhetö, néhány elemének makacs normativitása miatt a folyamat egésze összességében normatívnak tekintendő és akként kezelendö, azaz a politikai tevékenységek körébe sorolható. Ha ez így van, és a végeredmény elsösorban a koncepcionálás folyamatán és a döntéshozatalon múlik, akkor felvethető a kérdés, hogy érdemes-e a tervezöi racionalitást, egyes elemek objektivitását védelmezni, a tudományos megalapozottságot és tényszerủséget hangsúlyozni, vagy éppen ellenkezöleg, a kevésbé megalapozott szintézisre, a konceptualizálásra és a döntési folyamatra kell koncentrálni.

A normák egy társadalmi csoportban meglévő egyetértést fejeznek ki. A normakövetés általánosított viselkedési elvárás teljesítését jelenti, azaz már egy fönnálló normatív csoportegyeztetés fölelevenítése. A normavezérelt cselekvések megfelelö intézményekben, az annak megfelelő társadalmi rendben mani-fesztálódnak. Az aktorok normakonform módon cselekednek, de különbséget tehetnek cselekedeteik normatív és nem-normatív részei között. Ez feltételezi, hogy meg tudják különböztetni a szubjektív és az objektív világot.

A tervezés szükségszerú normativitásának belátásához elegendő, ha a tervezés alapvetö elöfeltételezéséböl indulunk ki, nevezetesen abból, hogy valamilyen formában és módon „tervezni pedig kell". Tehát a modem társadalomban a tervezés valamilyen formáját fölé helyezzük az ,ad hoc”, a spontán, a nemtervezett „elrendezési módoknak".

A tág értelemben vett tervezés szükségszerủen következik a demokratikus társadalom múködéséböl, a közakarat érvényesítéséböl. E gondolatok kapcsán nem Jean-Jacques Rousseau, James Mill és követőiknek gyakran citált tételeire hivatkozunk, hanem inkább Rousseau egy másik mủvében (Émile, 1762) kifejtett neveléselméletére, mely szerint a nevelésnek nem a gyermek megzabolázása a feladata, hanem fejlődésének elősegítése. A közösségi tervezésnek sem a kisebbség, más döntéshozók, a gazdálkodók vagy az egyén korlátozása az elsődleges célja, hanem közelebb jutni a közakarat hatékony megvalósításához, és elösegíteni a korszerủ értelemben vett fejlödést.

Az objektívnek tủnő vizsgálatokat is megelözi a kérdésfelvetés, amiben benne van valamilyen elözetes normatív értékítélet, amely befolyással van a később mért, 
észlelt jelenségekre. A tervezéstől nem normativitását, korlátozott racionalizmusát kell számon kérni, hánem a tervezés folyamatát, mechanizmusát, eszközeit kell fejleszteni.

A kommunikatív etika (Habermas 2001) azt a racionális elvárást fogalmazza meg, hogy a cselekvő (esetünkben a tervezö) hivatkozni tudjon cselekvése vezérfonalára, értékrendjére, amely alapján döntéseit hozta. A közszférában folyó tervezés során általában azzal találkozunk, hogy pragmatikus érvek (pl. forráshiány) és megfontolások (választási siker reménye) mögé rejtik a normatív választásokat. Így a döntések mögött meghúzódó normatív értékek rejtve maradnak - sokszor még önmaguk számára is -, az elöfeltevések kimaradnak a megmérettetésböl! Igen gyakran csak a szük szakmai érvek, az érték-semlegesnek (szcientista) feltüntetett globalizált érvrendszerek találkoznak a területileg és kulturálisan meghatározott életterekben gyökerező erkölcsi értékítéletekkel és materializálható érdekekkel. A tudományos ismereteket elöfeltételezö érveket a másik fél gyakran megérteni, söt minösíteni sem képes, így az ilyen kommunikáció nem vezet be-, illetve elfogadáshoz. A mai magyar politikai valóságban, sajnálatos módon, még normakonform viselkedésre sem lehet számítani. ${ }^{3}$ A kommunikáció hitelességének visszaállítása jó esetben is évtizedekbe kerülhet.

\section{Az utilitarizmus ${ }^{4}$ tétel-és problémakészletének néhány figyelemre méltó eleme}

A tervektől és azok megvalósításától minden esetben valamilyen eredmény (változás) bekövetkeztét, vagy még inkább érzékelhetö, mérhetỏ haszon elérését várjuk. A tervezéselmélet egyik alapvetỏ etikai, morális kérdése, hogy miként ítélhetö meg egyes tervezett cselekedetek helyessége és hasznossága. Abban egyezség mutatkozik, hogy a cselekedetek önmagukban nem megítélhetők, a viszonyítási alapban azonban a különbőzzö filozófiai és tervezési iskolák eltérnek. Sokan elfogadják azt az utilitarista megközelítést, amely az érintett emberekre gyakorolt hatást kívánja mérni, bár nyilvánvalóan sok esetben nem egyszerü az érintettek körének meghatározása és a különböző típusú előnyök (haszon, kényelem, boldogság stb.) és hátrányok (veszteség, kényelmetlenség, boldogtalanság stb.) összevetése.

Betham etikája alapján ${ }^{5}$ az egyes cselekedetek következményeinek számbavételekor a várható ,él vezetek és fájdalmak” - tágabb értelemben az elönyök és a hátrányok - mérlegelése során az alábbi körülményekre kell tekintettel lenni:

- intenzitás,

- tartalom,

- bizonytalansági tényezök,

- időbeni megvalósulás,

- annak esélye, hogy ugyanolyan elöjelủ következmények kövessék egymást,

- annak esélye, hogy a későbbiek során sem lesz ellentétes elöjelủ következménye a cselekedeteknek,

- az érintett személyek száma (Steiger 1997). 
Az előnyök és a hátrányok számbavétele és összevetése alapján tudjuk megítélni a tervezett cselekvés ,jó vagy rossz tendenciáját". Betham alaptételeit ${ }^{6}$ késöbb sokan sokféleképpen gondolták tovább ${ }^{7}$. Az utilitarizmusnak nem az eredeti alaptételei ${ }^{8}$, hanem inkább értékelési logikája adaptálható a tervezéselméletbe, és ezek az eredmények közvetlenül felhasználhatók az elözetes és az utólagos értékelések során. Ez alapján megfontolásra érdemes tanácsok adhatók a döntéshozók számára is.

Egy cselekedet helyessége a belőle származó jó vagy rossz következményektől függ. Jól választottunk, ha döntésünk következményei jobbak, mint bármely más helyette megtehetỏ cselekvésé. Döntéseinket a valószínü következmények alapján hozzuk (elözetes értékelés), de a tényleges minősítés a kontroll során, az „ex post” értékeléssel végezhetô csak el. Vannak cselekedetek, amelyekröl tudjuk, hogy minden esetben elkerülendők, de megoszlanak a vélemények a helyes döntésekröl olyankor, amikor bizonyosan közvetlen jó származna morális vagy de jure szabályok megsértésébőll, vagy ha a szabályok ellentmondásosak.

További kérdés, hogy egy hosszabb cselekvéssorozat eredménye önmagában minősíti-e az adott kontextusban (ott és akkor) meghozott döntést, illetve mi az értékelés alapja? Vannak esetek, amikor erre ,egyszerü” válasz adható (pl. háborús bủnök), de az esetek többségében elöre viszonyítási alapokat kell választanunk és biztosat csak e viszonyrendszeren belül állithatunk. Ugyancsak megoldhatatlan nehézségnek tủnik a különböző elöjelű következmények összevetése, illetve az időbeni eltérésből adódó összemérés. Az ilyen eseteket el kell kerülni a tervezés során az egyértelmủ megítélés érdekében.

A fenti dilemmák elkerülésére a gyakorlatorientált megközelítések általában azt ajánlják a tervezők számára, hogy olyan elemi részekre kell szétbontani a komplex kérdéseket, amelyek stabilan azonos - vagy csak negatív, vagy csak pozitív - elöjelủek és egzakt módon mérhetőek.

Habermas (2001) szerint a piac és a hatalompolitika hangolja össze a cselekvéseket, és ezek szabályozzák a személyközi (társadalmi) viszonyokat. Ilyenkor az egyes szereplők egymást instrumentalizálják, eszközként használják föl saját sikerük reményében. Habermas stratégiai cselekvésmodelljét is gyakran utilitarista módon értelmezik és az eredményt a célok elérésében mérik.

\section{Kommunikativ etika és cselekvés kérdésköre a tervezéselmélet megalapozásában}

A tervezés legkritikusabb eleme az ott és akkor „érvényes” normák, célok és prioritások meghatározása, ezek egyeztetése, összehangolása mások céljaival és az ezekkel kapcsolatos döntéshozatal. A hagyományos tervezési eljárásban a célok és a prioritások meghatározásának egyik inputját a megismert (!) tényekböl (,,cselekvéshelyzetböl") a hagyományosan elfogadott racionalitás alapján vezethetjük le, de legalább ilyen hatással lehet a stratégiaalkotásra a döntéshozó intenciója, szubjektív (politikai) akarata. 
A korszerü és demokratikus tervezési eljárásnak, mint interakciós eszköznek a feladata nem az, hogy a felkínált lehetöségek objektivitását kutassa és a döntéshozatalt ebbe az irányba terelje, hanem sokkal inkább az, hogy az elfogadásra ajánlott normák érvényességének megfelelően irányított kommunikáció útján egyességet alakítson ki, vagy elvesse azokat.

Egyre több társadalomelméleti kutatás ${ }^{9}$ irányul arra, hogy az egyes cselekvési alternativák érvényességét miként lehet megállapítani, illetve a nem-konszenzusképes normákat el tudjuk-e különíteni az elfogadásra alkalmasaktól. E kutatások arra az eredményre jutottak, hogy ha az egyes cselekvéstervek az adott életvilágban ${ }^{10} \mathrm{meg}_{\text {- }}$ felelöen levezetett kommunikáció eredményeként konszenzussal születnek, akkor azok érvényessége megfelel az ott kialakult és elfogadott normáknak. Ezen túl Habermas hozzájárulása a tervezéselmélet megalapozásához azért is fontos, mert foglalkozott a célt követő tevékenység struktúrájának és a racionális választás tisztázásával, a kommunikatív cselekvés magyarázatával.

Felkai G. (Habermas 2001, 11) Apelre hivatkozva írja, hogy „A megismeröcselekvő ember számára szükségszerủ előfeltevésnek, mintegy a priorinak mutatkozik az a reális kommunikációs közösség, amelyböl értelmezési teljesítményéhez történetileg áthagyományozott mintákat meríthet, $s$ ahol saját fogalmait, kijelentéseit - önmaga megértésének aktusában - szembesíti embertársai elképzeléseivel." A kölcsönös megértésre irányuló cselekvés az érvelés, a partnerek közötti diskurzus lehet, amely témánk szempontjából a tervegyeztetéseken zajlik. Ez csak akkor vezethet eredményre, ha az egész kommunikációs közösség hasonló alapnormákat vall, és azokat mindenki be is tartja ${ }^{1 "}$.

Habermas (1986) szerint az alapjaiban teleológiai szerkezetủ társadalmi cselekvés ${ }^{12}$ lényegi eleme a cselekvések összehangolásának mechanizmusa, mely lehetôvé teszi az interakciók szabályszerủ és állandó hálóinak a kialakulását. Megkülönbözteti a kooperatív és a stratégiai cselekvést és kommunikációt, amelyek a cselekvő szempontjából alternatívát jelentenek. Az elöbbi kölcsönös megértésre irányuló beállítódás alapján „egyetértéssel”, az utóbbi alapvetően „,befolyással” igyekszik létrehozni az összehangolt cselekvések alapját. $\mathrm{E}$ mechanizmusok egymást kizárják. Az interszubjektíven osztott meggyöződésböl közös tudás, egyetértés és kölcsönös kötelezettségvállalás ered, míg a külsődleges hatásgyakorlás megőrzi egyoldalúságát, és az egyetértés azonnal megszünhet, amikor az érintettek felismerik, hogy az a másik fél reá gyakorolt külsỏ befolyásából ered.

Tehát Habermas a kölcsönös megértésen alapuló kommunikatív cselekvéssel élesen szembe állítja a hatalmi igényekböl fakadó imperatív, sikerorientált - általa stratégiainak nevezett - cselekvést, amikor az egyik fél nem a másik érvekkel való meggyőzésére, hanem befolyásolására törekszik. Ezt akkor is törékeny konszenzusnak véli, amikor nem nyomásgyakorlás, hanem akár a másik fél által is elfogadott juttatások útján éri el a stratégia.

„Habermas szerint az ésszerú közmegegyezést úgy lehet elhatárolni egy uralkodó csoport vagy érdekszervezet - saját érdekei által vezérelt - eljárásaiban és döntéseiben megmutatkozó látszatmegegyezéstől, hogy megvizsgáljuk: vajon az érintettek 
mindegyike egyetértett-e volna a meghozott döntéssel, amennyiben azt ideális feltételek mellett lefolytatott vita előzte volna meg." (Habermas 2001, 28) Véleménye szerint ezt társadalomkritikai elméleti vizsgálatokkal el lehet dönteni.

Ez alapján végiggondolva a területfejlesztési támogatási rendszereket, amikor a területi, helyi közösségek pályázatokban, tervdokumentumokban megjelenő céljai, preferenciái a pályázati feltételeknek megfelelỏen kerülnek megfogalmazásra, negatívan értékelhetỏ. Igaza van Habermasnak, hogy ilyenkor nem a valós preferenciákat követi a forráselosztás és cselekvés, de ugyancsak Habermasra hivatkozhatunk, amikor azt állítjuk, hogy az anyagi haszonnal való kecsegtetés is az „életvilág”, a "cselekvéshelyzet" részének tekinthető. Sajnos a gyakorlatban nem „lefolytatható" és nem igazolható a feltételezett társadalomelméleti kritika sem annak igazolására, hogy csak ",részleges kompromisszumképes érdekeknek" megfelelően jött létre a konszenzus vagy ,általánositható érdekek" alapján. Egyszerü verifikáció lehetne az, ha pályázat nélkül adnánk a pénzt a helyi közösségeknek és megnéznénk, hogy ugyanarra fordítják-e erőforrásaikat, mint a pályázati feltételek között. Vélhetően nem, ami az eröforrások és a döntési kompetenciák decentralizációja mellett szól.

Habermas kommunikatív etikáját a gyakorlatban csak tér és idó korlátok között fogadhatjuk el. Az adott helyen és időben folytatott diskurzus során nem ismerhető meg és nem igazolható az ,általános érdek vagy normatíva”. Habermas kitétele is az, hogy „minden potenciális érintett egyetértésre jusson”, de csak az ott és akkor érvényes ismeretek és tudás alapján tudjuk meghatározni az érintetteket, illetve a potenciális érintettek sem biztos, hogy tudatában vannak az érintettségüknek. Továbbá, ha még minden érintett részt is venne a diskurzusban, akkor sem biztos, hogy mindenki szavakban ki tudja fejteni véleményét, meg tudja fogalmazni érdekeit, illetve képes megérteni és befogadni mások érveit. A transzkulturális kommunikáció eredményességét feltétlen kétségesnek érezzük. A megfelelően lefolytatott tervezési eljárás sokat segíthet a kommunikáció alakításában.

Ha saját életviláguk hagyományai alapján, etikai-politikai viták során egy közösség minden tagja tudatosította "hogy mi a jó nekik”, akkor is még az így kialakított norma ütközhet más közösségek ugyanilyen eljárás során kialakított normáival. Ha újra kezdik a diskurzust egy szélesebb körben, és mindenki kölcsönösen belátja mi áll érdekében, a kialakult új normák ismét ütközhetnek másokéval, és nem is számoltunk a jövő generációival, mint potenciális érintettekkel, akik részt sem tudnak venni a vitában.

A tervezés során természetesen törekedni kell a közös tudáson alapuló értékkonszenzus kialakítására, de attól tartunk, a gyakorlatban mégis meg kell elégedni a „stratégiai cselekvésmodell” megvalósításával. A sikerorientált cselekvő jó esetben „,belső” (egy közösségen belüli) döntését konszenzussal hozza meg, de a megvalósítás során felmerülhetnek olyan helyzetek, amikor szembe kell helyezkednie azokkal a cselekvésekkel, amelyek veszélyeztetik „cselekvés-tervének” megvalósítását. Tipikusan ilyen helyzet a szükösen rendelkezésre álló fejlesztési forrásokért folyó harc. Területileg interpretálva e gondolatokat, az adott területi egységen belül a közös tudáson alapuló egyetértésre építhetỏ a terv, de kifelé már habermasi érte- 
lemben stratégiai cselekvésmodellé alakul a teleológiai cselekvés. Ennek hiányában egy véget nem érö egyeztetési folyamat lenne bármilyen szándék megvalósítása nélkül. Például nem lehetséges egy méretgazdaságosságon alapuló termelö kapacitást szétaprózni, és mindenhová telepíteni, ahol munkanélküliség van, vagy a keletkező hulladékot akkor is kell valahol deponálni (vagy megsemmisíteni), ha ,a szerepet önként értelmezve" egyik közösség sem vállalja magára, csak ha megteremtik érdekhelyzetét, és ha kell, azt hatalmi eszközökkel is „fenntartják”.

További kritikus elem, hogy kiket tekintsünk kommunikációs partnereknek. Filozófiai síkon a „paraméterek” könnyen megadhatók, de a politikai életben soha nem lehet kialakítani az ideális kommunikációs közösséget, csak a konkrét történelmi helyzetnek megfelelö reálisat. Másrészt, akinek kezdeményezési, tervezési jogosultsága van, annak manipulációs lehetősége is van, hacsak nem sikerül az ideális állapotnak megfelelöen bürokratikusan szabályozni a folyamatot.

\section{A tervezés fogalma (helyett lényegének körülírása) és maximái ${ }^{13}$}

A tervezésnek nem lehet olyan definícióját megfogalmazni, amely valamennyi történeti korszakára és iskoláira érvényes lenne, mert nem állandó sem tárgya, sem módszere, sem formája, és a különböző (politikai) kultúráknak is más fogalmuk van a tervezésröl. Bonyolítja a helyzetet, hogy a tervezést, mint eszközt a gazdaság és a társadalom alapegységei éppen úgy használják, mint például a kormányok és különböző szupranacionális közösségeik. Az pedig különös pikantériát ad a dolognak, hogy a fasizmus és a proletárdiktatúra éppen úgy alkalmazta, saját (,,közpolitikai”) céljai elérése érdekében, mint ahogyan a polgári demokráciákban a közös cselekvések meghatározásához próbáljuk használni. Tehát nagyon nehéz általánosságban tárgyalni, konkrét tértől és időtől, történelmi-politikai kontextustól függetlenül. Ennek ellenére megkíséreljük az esetek többségében létező lényeg meghatározását, és az általunk érvényesnek vélt jelenlegi maximák megfogalmazását, mert valahol ez jelöli ki a tervezéselmélet tárgykörét, tétel- és fogalomkészleteinek határait.

A tervezés lényegi elemeinek keresésekor két korlátozó megszorítást teszünk, amelyeket a későbbiekben paradigmatikusan kezelünk:

- a tervezés közösségi tevékenység,

- a mai értelemben vett tervezést a modern kortól datáljuk és ez vizsgálatunk tárgya.

A modern tervezést történeti tanulási folyamat eredményeként kialakult társadalmi kényszernek tekintjük, amely a felvilágosodás tradícióiban gyökerezik, és szoros kapcsolatban van a modernizmussal. A szabad individuumoknak és gazdasági tevékenységeiknek kezelni, koordinálni kellett közös ưgyeiket. Hittek abban, hogy ha a közös cselekedetek során a meglévő tudást racionálisan alkalmazzák, akkor ,jobb világot" lehet építeni és a jólét ilyen módon mindenki számára növelhető. Egyre inkább nyilvánvalóvá vált az is, hogy a jelen cselekedeteket a jövő figyelembevételével kell alakítani, elöre kontrollálni kell a folyamatokat. 
Mára viszont az is világossá vált, hogy az intellektuális és politikai felvilágosodásban gyökerező modern tervezés, amely összeforrt a demokrácia és a haladás mítoszával, gyakran nem érte el célját. Nem a kitúzött célokban, a felvilágosodás eszméivel volt, van a baj, hanem azzal, ahogy az állampolgárok és csoportjaik nem tudják kezelni közös cselekedeteiket térben és idöben, a természeti- és közjavak egymás közötti elosztásában.

A megoldást a marxizmus klasszikusai a központi tervgazdálkodás bevezetésében látták, de Mises és Hayek már a húszas, harmincas években felhívták ennek ellentmondásaira a figyelmet, és a próbafuttatás a „létező szocializmussal” együtt megbukott. A fejlett piacgazdaságok polgári teoretikusai is az állam szervező, irányító funkcióinak a kiterjesztésében látták a megoldást, amely átfogó, többszintủ és többszereplös tervezési rendszer müködtetését jelentette. Az elmúlt évtizedekben egyre gyakrabban és egyre többen bírálták a szakracionálisnak feltüntetett döntéshozatalon nyugvó modern tervezést (pl. Friedmann 1973; 1987; Faludi 1986). Többek között Castells (1977) marxista gondolatmenetben igazolta, hogy a kapitalizmusban az állampolgárok céljai helyett a töke céljai érvényesülnek, és a környezetvédelemmel foglalkozó tervezök is azt tapasztalták, hogy nem lehet a környezeti szempontokat megfelelően érvényesíteni a tőke igényeivel szemben. A kritikák sorát olvasva a modern tervezés hallatán egyre inkább az uralkodó hatalom akaratának megfelelö „rendszerezett értelem” állami bürokráciával történö megvalósitására asszociálhatunk.

Az uralkodó felfogás megkérdőjelezése még nem jelenti a tervezés alapjainak teljes kiüresedését. Az érdektelenség, a tervezés elvetése helyett sokan a társadalmi konszenzus keresésének új módjait kutatják. A tervezéselmélet kutatói az elmúlt két évtizedben alapvetően két gondolkodó, Michel Foucault és Jürgen Habermas munkásságára koncentrálnak. Mindkét filozófus ráirányította a figyelmet a kommunikáció és a nyelv jelentöségére. A posztmodern Foucault az utóbbi évtizedben került a tervezéselmélet látókörébe, azzal, hogy a korábbiakhoz képest másként határozta meg a hatalom mủködését, új megvilágításba helyezte a tervezést, mint a hatalom gyakorlásának eszközét/intézményét. Különösen azok a gondolatmenetei fontosak, amelyek arra irányultak, hogy különböző történelmi helyzetekben $a$ hatalom miként viszonyult az elfogadott tudáshoz, milyen ,igazságot” jelenített meg ,közérdekként". Habermas azt vizsgálja, hogy a modern társadalom hogyan müködhet demokratikusan, a kommunikáció hogyan javíthatja ennek esélyeit. Kifejti, hogy az autonóm individuumok öntudatára építỏ logika és tudomány helyett be kell vezetni az értelem, a gondolkodás új fogalmát. Ez az egymás kölcsönös megértésén, helyileg és történetileg meghatározott kommunikáción alapul. Kellő támpontot nyújthat a közös cselekvések megalapozásához - a tervezéshez - ,az életvilág ... a kulturális hagyományok folytatása, a csoportok integrációja normák és értékek segítségével, és a felnövekvő generációk szocializácója" (Habermas 1998, 244). Elmélete alapján a tervezés megújulása is épülhet a „kölcsönös megértésre orientált cselekvés modelljére". Az emberek az interperszonális kapcsolatok révén kölcsönösen korlátozott perspektívákat jelölhetnek ki, az egyes értékek mentén csoportok szervezödhetnek és a szolidaritásukra alapozott perspektívának megfelelően koordinálhatják 
cselekvési terveiket. A tervezéselméletben többen igyekeznek összekötni a foucaulti hatalomelméletet a habermasi kommunikatív racionalitás elméletével és olyan tervezési játékteret létrehozni, ahol a hatalom pozitív (?) módon érvényesül.

Sajnos ez ma még csak vonzó idea, a tervezéselmélet foglalkozik ezekkel a kérdésekkel, de a gyakorlati tervező munkában alig történtek erre bizonyíthatóan sikeres kísérletek ${ }^{14}$. E poszt- vagy promodern romantikának még alig van kézzelfogható eredménye, de kétségtelen, hogy a tervezés paradigmáinak változása megkezdödött. E változásokról a különböző iskolák másként vallanak, de mégis megfogalmazhatók az alapvető különbségek a korábbi modernista tervezési hagyományok és az újabb törekvések között. Az 1. táblázat felsorolásában nem törekedtünk a teljességre, hanem elsősorban a változások, elmozdulások irányait szeretnénk ezzel jelölni.

\section{TÁBLÁZAT}

A tervezésre ható paradigmák változásának irányai

(Direction of Paradigm's Changes Effecting Planning)

\begin{tabular}{|c|c|c|}
\hline MODERN & & „POSZTMODERN”* \\
\hline \multicolumn{3}{|c|}{ Ideológia } \\
\hline totalizáló & & elméletek egymásmellettisége \\
\hline & A tervezés alapja & \\
\hline $\begin{array}{l}\text { a valóság megismerése, az ob- } \\
\text { jektív tudás és a racionalitás }\end{array}$ & & $\begin{array}{l}\text { szubjektumok megértése, törté- } \\
\text { nelmileg és helyileg meghatáro- } \\
\text { zott „,kommunikatív ész” }\end{array}$ \\
\hline \multicolumn{3}{|c|}{ A tervezés eszköze, módszerei } \\
\hline $\begin{array}{l}\text { tudományos racionalizmus, } \\
\text { tudományosan igazolt modellek, } \\
\text { sablonok, mércék }\end{array}$ & & $\begin{array}{l}\text { konszenzus-keresés, adott kon- } \\
\text { textusban érvényes eljárások, } \\
\text { értelmezés-minták, kulturálisan } \\
\text { begyakorlott feltevések }\end{array}$ \\
\hline & A terv feladata & \\
\hline allokálás, megszab, korlátoz & Állampolgár & lehetőséget teremt, kereteket ad \\
\hline a tervezés tárgya és végrehajtó & & aktív szereplő \\
\hline racionális szakember & 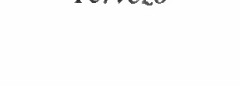 & $\begin{array}{l}\text { moderátor, katalizátor, szubjek- } \\
\text { tív szakember }\end{array}$ \\
\hline & Támogatja & \\
\hline a legfejlettebb technológiát & Tervezés & a megfelelő technológiát \\
\hline dokumentum készítése & & $\begin{array}{l}\text { interaktív és interpretatív folya- } \\
\text { mat, társadalmi cselekvés, } \\
\text { argumentatív eljárás }\end{array}$ \\
\hline $\begin{array}{c}\text { centralizált hatalmi struktúrában } \\
\text { a politikusok }\end{array}$ & Döntéshozatal & $\begin{array}{c}\text { társadalmiasult individuumok } \\
\text { decentralizált csoportjai }\end{array}$ \\
\hline standardizálást, uniformalizálást & A terv preferálja & egyediséget, flexibilitást \\
\hline nagy (gazdasági) szervezetek & Célszervezet & kis szervezetek, civil társadalom \\
\hline
\end{tabular}

* A posztmodern jelzőt - jobb kifejezés híján - az újabb trendek ơsszefoglaló neveként használjuk.

Forrás: Saját szerkesztés. 
A trendek kitapintása után feltehetjük a kérdést, mit érthetünk ma tervezésen, mit tekinthetünk meghatározó elemeinek? Tág értelemben egységesen tervezésnek nevezhetjük a céltudatos elörelátás és az annak alapjăn való cselekvés véges számú variációját, mert a heterogén részeit hasonló szándékok és hagyományok fogják össze. Minden tervezési tevékenység a jövőben bekövetkező problémák elkerülése vagy jobb eredmény elérése érdekében teendöket, cselekvés sorozatokat határoz meg, vagy ez által kíván úrrá lenni bizonyos helyzeteken. A lényeg az, hogy a véletlennel, az esetlegessel állítjuk szembe a tervszerüen rendszerezett lépéseket.

A közösségi szférában folyó tervezés általunk ma érvényesnek vélt maximái:

- teleológiai társadalmi tevékenység,

- valamely rendszer jövőbeni irányítását szolgálja (a ma tudásszintjén jövöorientált),

- racionális (tudományos) és normatív (politikailag meghatározott),

- az aktuális tudást célirányosan cselekvésekké alakítja,

- többszintủ és sokszereplős,

- elfogadja a közszféra - szükség esetén történő - beavatkozását a magánszférába,

- explicit és jól artikulált,

- jól strukturált, formalizált eljárásrendet követ,

- a kommunikáció egy sajátos megjelenési formája, a folyamat dokumentumai, a tervek a nyelvi kommunikáció objektivációi.

A ,jó" müködés (a maximák érvényesülésének) peremfeltételei:

- átláthatóság,

- információkhoz való hozzáférés,

- szakszerüség (elvárható tudás és a szükséges eszközök biztositása),

- kontrolláltság,

- garantálni kell (jogszabályokban) minden potenciális érintett számára, hogy megadott helyzetekben részt vehessen a tervezés folyamatában, véleményét kifejthesse, és a tervezőknek és a döntéshozóknak (idö- és költségkorlátok között) törekedniük kell az összes potenciális érintettel történő egyeztetésre, a kölcsönös megértésre.

Tehát a lényeget röviden összefoglalva: a tervezés a sikerorientált intencionális (teleológiai) társadalmi cselekvés egyik jól strukturált instrumentális módja, az (ex ante) irányitás explicit eszköze. A terv pedig a szándékolt cselekvések egy adott pillanatban rögzített (előrevetített) képe, a normákkal átszött társadalmi cselekvés objektivációja. Használatát a társadalmi normák, vagy esetenként azokat szakaszosan követő jogszabályok szabályozzák. A tárgyiasulás nem elsősorban a megvalósítás érdekében szükséges, hanem az átláthatóságot, a véleményezhetőséget, a partnerség elvének teljesíthetőségét és a számon kérhetőséget szolgálja, mértéket ad.

Végezetül újra azt hangsúlyozzuk, hogy a tervezés fegyelmezett, racionális eljárásmód, ahol a racionális jelző mindenekelött formai értelemben használatos, az eljárás logikai rendszerére és nem az integrált döntésekre vonatkozik. Felbontani, elemezni, módszereket kiválasztani és alkalmazni lehet racionálisan, de ugyanez 
nem mindig vonatkozik a szintetizálásra és a döntéshozatalra, amely inkább normativ. Ugyanakkor a tervezési eljárás betartása és lefolytatása segiti, hogy a szintetizálás minél inkább megfeleljen a megszerezhetö tudásnak és az adott kontextusban érvényes társadalmi normáknak!

\section{Jegyzetek}

'Jelen esetben a vulgarizálás nemcsak célszerü, hanem szükségszerü is, mert néhány filozófiai tétel kiemelésével és jelen összefüggésben való felmutatásával nincs lehetőség arra, hogy például az eredeti terminológiákat használjuk, annak értelmezése nélkül, vagy bővebben kifejtsük egy-egy filozófus tanait, esetleg uitköztessük azokat más nézetekkel.

2 „A munkás nemcsak létrehozza a természeti dolog formaváltoztatását, hanem egyúttal a természeti dologban megvalósítja saját célját, amelynek tudatában van, amely törvényként meghatározza cselekvésének útját-módját, s amelynek alá kell rendelnie akaratát." (Marx 1967, 169)

${ }^{3}$ Hacsak nem a hazug vagy ,korlátozott” kommunikációt tartjuk normakonformnak.

${ }^{4}$ Az utilitarizmus etikai irányzat, melynek megalapozója a brit Jeremy Betham (1738-1832). Utilis latinul hasznosat jelent.

5 J. Betham Bevezetés az erkölcs és a törvényhozás c. mủvének IV. fejezetét Bence Gy. fordításában idézi Steiger K. (1997).

6 „A hasznosság elvén azon princípium értendö, mely bármiféle cselekedetet ama tendenciájának megfelelöen helyesel vagy helytelenít, amellyel az ama fél boldogságát növeli vagy csőkkenteni látszik, kinek érdeke szóban forog: (...) ha ez a fél a közösség lenne általában, úgy a közösség boldogságát (...)." (An Introduction to the Principles of Morals and Legislation, 1789. Idézi: Bánki 1993, 343)

${ }^{7}$ Témánk szempontjából fontosabbak: J. S. Mill, G. E. Moor filozófusok munkái.

${ }^{8}$ A cselekedetek helyességét nem tudjuk lemérni az emberi boldogság növelésén vagy a nyomorúság csökkentésén, mert ezek nehezen mérhető szubjektív és relatív kategóriák, a kettő össze sem vethetö.

${ }^{9}$ Különösen fontos Jürgen Habermas és Karl-Otto Apel munkássága, de meg kell említeni Ludwig Josef Johann Wittgenstein hozzájárulását is.

10 „Az életvilágot, amennyiben értelmezési erőforrásként vesszửk figyelembe, háttérföltevések olyan, nyelvileg szervezett készleteként képzelhetjük el, amely a kulturális áthagyományozódás formájában reprodukálódik." (Habermas 1986, 189)

${ }^{11}$ E tétel alapján nem jöhet létre valós konszenzus egy terrorista szélsőséges iszlám csoport és a nyugati civilizáció életvilágában felnőtt emberek között, még akkor sem, ha egyenrangú félként vesznek részt a tárgyalásokon.

12 „A társadalmi cselekvếs példaszerủ esetetét bizonyosan aktorok (legalább két aktor) egyuüttmüködése képezi, akik instrumentális cselekvéseiket egy közös cselekvésterv véghezvitele érdekében hangolják össze." (Habermas 1986, 175-176)

${ }^{13}$ Kant nyomán azokat a tervezési szabályokat és elveket nevezhetjük a tervezés maximáinak, amelyekhez a gyakorlatban - megfelelö ismeretek birtokában - igazodni kellene. Ezek konzisztens betartása a ma elfogadott tudásszintnek és normáknak megfelelő tervezöi gyakorlat kialakításához vezetne. A profán szóhasználatban és a tervezési gyakorlatban egyaránt az adott kontextusban érvényes preferenciákat jelentik.

${ }^{14}$ A kilencvenes években, elsősorban Angliában már találkozhattunk ilyen kísérletekkel.

\section{Irodalom}

Bánki D. (szerk.) (1993) Filozófiai kisenciklopédia, a nyugat filozófíaja és filozófusai. Kossuth Könyvkiadó, Budapest.

Barakonyi K-P. Lorange (1991) Stratégiai management. Közgazdasági és Jogi Könyvkiadó, Budapest. Castells, M. (1977) The Urban Question. Edward Arnold, London.

Dror, Y. (1971) Ventures in Policy Sciences. Concepts and Applications. American Elseiver P.C., New York. 
Faludi, A. (1973) Planning Theory. Pergamon Press, Oxford.

Faludi, A. (1986) Critical Rationalizm and Planning Methodology. Pion, London.

Friedmann, J. (1973) Retracking America. Anchor, New York.

Friedmann, J. (1987) Planning in the Public Domain. Princeton University Press, New Jersey.

Habermas, J. (1986) Magyarázatok a kommunikatív cselekvés fogalmához. - Magyar Filozófiai Szemle. 1-2. 175-200. o.

Habermas, J.(1998) Filozófiai diskurzus a modernségröl. Helikon Kiadó, Budapest.

Habermas, J. (2001) A kommunikatív etika. Új mandátum Kiadó, Budapest.

Kant, I. (1966) Az ítéleterö kritikája. Akadémiai Kiadó, Budapest.

Kant, I. (1991) A gyakorlati ész kritikája. Gondolat Kiadó, Budapest.

Lefebvre, H. (1949) Formális logika, dialektikus logika. Hungaria Könyvkiadó, Budapest.

Márkus Gy. (1971) Marxizmus és „,antropológia." Akadémiai Kiadó, Budapest.

Marx, K. (1967) A töke. Marx-Engels Müvei. 23. kötet. Kossuth Kiadó, Budapest.

Steiger K. (1997) Filozófia. Holnap Kiado, Budapest.

\section{SLICES FROM THE DEPTH OF PLANNING}

\section{LÁSZLÓ FARAGÓ}

The first chapters of the study discuss some epistemological, ethical and utilitarian dilemma of planing theory. After the review of the changing orientation of paradigms effecting planning, the author tries to define the concept, main rules and principals of public planning. In his opinion planning is the well-structured method of success oriented teleological activity and the tool of ex-ante direction. While planning document is one of the objectivated forms of social activity covered with the above mentioned norms. 